Interactive and socially inclusive pedagogy:: A comparison of practitioner- and childoriented cognitive/learning activities involving 4 year-old children in pre-schools in

\title{
England
}

Peter Kutnick $^{\mathrm{a} 1}$, Antonella Brighi ${ }^{\mathrm{b}}$, and Jennifer Colwell ${ }^{\mathrm{c}}$

${ }^{\mathrm{a}}$ Faculty of Education, The University of Hong Kong, Hong Kong SAR

bScienze Dell’Educazione, University of Bologna, Italy

${ }^{\mathrm{c}}$ School of Education, University of Brighton, UK

\footnotetext{
${ }^{1}$ Corresponding author: pkutnick@hku.hk
} 


\title{
Interactive and inclusive pedagogy: A comparison of practitioner- and child-oriented
}

\author{
cognitive/learning activities involving 4 year-old children in pre-schools in England
}

\begin{abstract}
:
This study describes the social contexts in which 4 year-olds undertake practitioner assigned cognitive/learning tasks within pre-schools and the different experiences these contexts provide for children. Data was collected in thirty-four pre-school settings in South East England, using a phenomenographic mapping of activities and social groupings during learning activities. The data was subject to frequency-based analyses. Results identified distinct social pedagogic contexts wherein children interacted with practitioners or with peers; these contexts were differentiated by group size and composition, activity, type of interaction with practitioner and peers, level of cognitive challenge and genderization of activity. The results revealed that while children engaged in cognitive/learning activities within both practitioner- and child-oriented pedagogic worlds the nature of the activities within these social contexts emphasised interactive inclusion and interactive exclusion respectively.
\end{abstract}

French Summary:

Cette étude décrit les contextes sociaux dans dont 4 ans accomplissent des tâches cognitives / d'apprentissage professionnel affectés dans les écoles maternelles et les différentes expériences de ces contextes offrent aux enfants . Les données ont été recueillies dans trentequatre paramètres pré- scolaires dans le Sud Est de l'Angleterre, à l'aide d'une cartographie phénoménographique des activités et des groupes sociaux au cours des activités d'apprentissage . Les données ont été soumises à des analyses basées sur la fréquence . Résultats identifiés contextes pédagogiques sociale distincts, dans lequel les enfants interagissent avec des praticiens ou avec les pairs ; ces contextes sont différenciés par la taille du groupe et la composition , activité, type d'interaction avec le praticien et pairs , le niveau de défi cognitif et sexualisation de l'activité . Les résultats ont révélé que, bien que les enfants engagés dans des activités cognitives / d'apprentissage dans les deux praticiens- et mondes pédagogiques axés sur les enfants de la nature des activités au sein de ces contextes sociaux souligné l'inclusion et de l'exclusion interactif interactive respectivement .

German Summary:

Diese Studie beschreibt die sozialen Kontexte der davon 4 -Jährigen verpflichten Arzt zugewiesen Kognition / Lernaufgaben in Kindergärten und die unterschiedlichen Erfahrungen diese Kontexte bieten für Kinder. Die Daten wurden in vierunddreißig Vorschul Einstellungen in South East England gesammelt , mit einem phenomenographic Zuordnung der Tätigkeiten und sozialen Gruppierungen während der Lernaktivitäten . Die Daten wurden unter frequenzbasierte Analysen . Ergebnisse identifiziert verschiedene sozialpädagogischen Kontexten , wobei Kinder mit Praktikern oder mit Gleichaltrigen zu interagieren , diese Zusammenhänge wurden von der Gruppengröße und Zusammensetzung , die Tätigkeit , die Art der Interaktion mit Gleichaltrigen und Praktiker , Grad der kognitiven Herausforderung und genderization der Tätigkeit unterschieden. Die Ergebnisse zeigten , dass , während die Kinder in der kognitiven / Lernaktivitäten innerhalb der beiden Praktiker -und kinderorientiertepädagogische Welten beschäftigt die Art der Tätigkeiten innerhalb dieser sozialen Kontexten betont interaktive Integration und interaktive Ausgrenzung auf. 


\section{Spanish Summary:}

Este estudio describe los contextos sociales en los que 4 años de edad realizan tareas cognitivas / de aprendizaje profesional asignadas dentro de los centros preescolares y las diferentes experiencias de estos contextos proporcionan para los niños. Los datos fueron recogidos en treinta y cuatro ajustes pre - escolares en el sudeste de Inglaterra , utilizando un mapeo fenomenográfico de actividades y agrupaciones sociales durante las actividades de aprendizaje . Los datos fueron sometidos a análisis basados en la frecuencia. Resultados identificaron contextos pedagógicos sociales distintas en donde los niños interactuaron con profesionales o con los compañeros ; estos contextos se diferencian por el tamaño del grupo y la composición , actividad, tipo de interacción con el médico y los compañeros , el nivel de desafío cognitivo y genderization de actividad. Los resultados revelaron que mientras los niños participan en actividades cognitivas / de aprendizaje dentro de los dos -y practicante mundos pedagógicos orientados a los niños a la naturaleza de las actividades dentro de estos contextos sociales hicieron hincapié en la inclusión y la exclusión interactiva interactiva respectivamente.

Key words: inclusive pedagogy, social pedagogy, pedagogic worlds, activity theory, cognitive challenge

\section{INTRODUCTION:}

There are now a number of well founded, international studies identifying that access to preschool experience will enhance a child's cognitive and social development and facilitate entry to primary schools (Ball 1994; NICHD 2002; Schweinhart, and Weikart 1997; Sylva et al. 2010). These studies demonstrate that the analysis of the potential positive effects of preschool experience on children's development have moved-on from simple considerations of attendance to the investigation of specific qualities associated with effective environments and activities or high quality experiences (EPPE 2004; Siraj-Blatchford 2010; Sylva 2010). Of particular relevance is that pre-schools providing high-quality or 'excellent' provision provide for both cognitive and social development and that these developments are not compartmentalised, they are linked (Siraj-Blatchford et al., 2003). The study reported within this paper examines childrens' experiences within pre-school settings (associated with interactions between children and their practitioners) that facilitate cognitive and social developments - especially with regard to an active and interactive pedagogy and the promotion of social inclusion (EPPE 2004; Stephen 2006). In particular, the EPPE studies 
(reviewed in Sylva et al. 2010) and other related reviews (see Stephen 2006) in the UK identify that effective environments and activities in pre-schools place particular focus on an interactive pedagogy and the fact that pre-schools cater for a 'diversity' of children. While we rely on the evidence of large-scale studies of pre-schools to understand the contribution to, and general effects of, participation in pre-school environments (and children's backgrounds), this paper has chosen to explore how pedagogy and diversity take place within pre-school settings. Thus, the paper draws from a depth of observation rather than a breadth of comparisons.

It is our view that the terms of interactive pedagogy and social inclusion may be seen to combine as an 'inclusive pedagogy' within pre-schools where the removal of barriers to learning for all children is created in an interactive context which can foster processes of knowledge co-construction: 'Going hand in hand with inclusive pedagogy is the connection to socio-cultural theory where learning is understood to be influenced by relationships between people, contexts, actions, meanings, communities and cultural histories’ (Edwards 2003 cited in Deans 2009, p.2). Few pre-school studies currently exist that specifically explore processes that may be associated with an inclusive pedagogy (Siraj-Blatchford 2010); although one of these studies has questioned the consistency of results with regard to children’s development (Early et al. 2007) suggesting that it would be naïve to assume that the simple fact of having access to pre-school with interactive and inclusive pedagogic guidelines will ensure effective and consistent cognitive and social development amongst young children.

\section{An Interactive/Inclusive Pedagogy?}

In order to further the understanding of interactive/inclusive pedagogic processes associated, in particular, with 'effective provision of pre-school education’ (EPPE 2004) we suggest the need for a more detailed analysis of the cognitive and social activities that are undertaken 
within pre-school settings. This analysis will take us beyond general descriptions of supportive, non-directive, scaffolding organized by practitioners and additionally identify the active/agentic role played by children (Clark et al. 2003; Siraj-Blatchford, and Sylva 2004; Woodhead, and Faulkner, 2000). One example of cognitive and social activities associated with interactive/inclusive pedagogy is found in Siraj-Blatchford (2010)'s description of ‘sustained shared thinking’ within adult-child and child-peer communicative interactions. Siraj-Blatchford notes that the pedagogy involved is something more than 'instructional techniques and strategies that enabled learning to take place' (p.149). Further, we reintroduce a concept of ‘social pedagogy’ (from Myrdal 1945) which acknowledges the child's role in a pedagogic relationship ‘to empower children as active citizens so that they may change their lives’(p.396). This social pedagogic approach, though, is most likely to take place in an environment of cognitive challenge and where both children and adults can initiate pedagogic activity (from Stephen 2006). The effective pre-school is seen as interactive - where practitioners set-up the learning environment and scaffold children in their activities and children are active in their co-construction of the learning and social environment. Thus, while the pre-school learning and social environment is often characterized, in a dichotic manner, with regard to adult-structured (cognitively-oriented) ‘learning' and child initiated 'play’, many studies (Sylva et al. 2010; Goble et al. 2012; Kutnick et al. 2008) recognize the importance and substantive amount of time that children spend in semi-structured (learning) activities with or without an adult present that is neither 'play' or formally 'taught' by the practitioner.

An expansion of Myrdal (1945)'s concept social pedagogy notes development in preschools is as likely to take place in a child-peer social context as it is in a child-practitioner social context (Kutnick, and Brighi 2007) especially when children spend at least half of their time undertaking cognitive/learning activities prepared by their practitioners in peer groups 
with no adult present (Kutnick, and Brighi 2007; Singer 1996; Tizard et al. 1988; Tizard, and Hughes 1984). In expanding the concept, Myrdal's notion of child empowerment is maintained while acknowledging (from Kutnick, Blatchford, and Baines 2002) that social pedagogy describes the social context within which pedagogic relationships take place. This definition of social pedagogy questions: 1) what forms of interactive/inclusive pedagogy are in use in pre-school settings beyond the practitioner-child relationship; and 2) does this social pedagogy promote both inclusion as well as cognitive/social development.

At this point, the writers note that the term 'inclusion' has been represented in the preschool literature from a number of perspectives, and these perspectives focus on (at least) three themes: First, and perhaps most frequently cited, is the mainstreaming of children with special educational needs (SEN) into normal pre-school settings (see Nutbrown, and Clough 2004; Odom 2000; Odom et al. 2002). Second, and often tied to the development of comprehensive pre-school opportunities for all children is the social inclusion of children, especially children from educationally 'disadvantaged' and diverse backgrounds, to overcome societal processes of exclusion (Brandsma 2003; Harrist, and Bradley 2003; Social Inclusion and Early Childhood Development 2009; Sylva 2010). Third, and less frequently explored, is gender-based inclusion where particular social contexts have been characterized by the integration or separation of boys and girls (extensively researched by Fabes and colleagues: Fabes, Hanish, and Martin 2007, 2003; Goble et al. 2012; Martin 2000; also see Fanger, Frankel, and Hazen 2012). Similar to general studies of effective provision of preschool education, inclusion studies have mainly been undertaken as large-scale comparisons with only a few qualitative studies to explore how processes of inclusion/exclusion take place in pre-school settings. Thus, while an interactive/inclusive pedagogy appears strongly associated with positive cognitive and social outcomes of pre-school experience, we must 
also be aware that 'interactive' pedagogy will take place in particular social contexts which may or may not promote social inclusion.

\section{Social Pedagogy of cognitive/learning contexts within the pre-school setting:}

Until the series of EPPE studies (Sylva et al. 2010), pre-school learning often separated contexts of cognitive from social development. Cognitive development has associated particular activities with school preparation and learning of academic skills in a cognitively challenging environment (Stephen 2006). Social development has associated free play activities and non-practitioner prescribed activities with social competence (see Buysse, Goldman, and Skinner 2003; Kontos 1999; Smith, and Connelly 1980). Both cognitive and social activities require some interpersonal involvement/interaction but there has been a distinction between the two types of activity. Within cognitive activities, children's interactions have often been described as taking place with adults who direct or scaffold the learning activity (DfEE/QCA 2000); allowing for activities to be both child or practitioner initiated - but ‘children’s cognitive outcomes appear to be directly related to the quantity and quality of the practitioner/adult planned and initiated focused group work' (EPPE 2004, p.5). It is also assumed that time spent in cognitive/learning activities is: active - where the child is seen as a social agent (Woodhead, and Faulkner 2000); interactive between the child, practitioner and, at times, peers (Clark et al. 2003); inclusive in that children interact with others who may be of a different sex, ethnicity, or with various special educational needs (Bertram, and Pascal 2002; Nutbrown, and Clough 2004; Singer 1996; Siraj-Blatchford, and Sylva 2004); and associated with higher levels of cognitive functioning (in early numeracy and literacy) that will ease the child's transfer into primary school (Sammons et al. 2004; Schweinhart, and Weikart 1997).

Social development has been characterized by activities that the child chooses to undertake with peers, seen predominantly in studies of free play. These activities: have low 
levels of practitioner involvement (Pellegrini, and Perlmutter 1989); are less focused than cognitive tasks (Guay, Boivin, and Hodges 1999)²; and are likely to take place in gendered and friendship-based peer-groupings that demonstrate exclusion (by sex, ethnicity, social status and special educational needs; Fabes et al. 2003; Gunn et al. 2004; Kontos, and Wilcox-Herzog 1997; Lofdahl, and Hagglund 2006). Pre-school studies that focus predominantly on cognitive or social activities have led to conclusions of distinctiveness, where: 1) cognitive activities tend to be (directively) structured and scaffolded by a practitioner and undertaken in a socially inclusive manner - usually with a practitioner present; and 2) social activities tend to be unstructured, undertaken with peers, do not have a practitioner present, and may represent socially exclusive interactions. Yet, this breakdown of pre-school activity into cognitive and social is unlikely to characterize children's actual experience - especially related to the potential of learning by activity. As previously noted, children often spend a substantial amount of their time in 'semi-structured' activities (see previous references to EPPE 2004; Goble et al. 2012) which include combined aspects of cognitive and social. From observations (see Kutnick et al. 2008) of pre-schools, semistructured activities: usually take place during 'learning' as opposed to 'play' time (when the practitioner is usually occupied with a particular group of children and semi-structured characterizes the actions undertaken by the other children in the class); the activities are setup by the practitioner with various levels of cognitive challenge; and children are free to choose which activity to undertake and with whom they undertake the activity.

Further, while these pre-school pedagogic settings present a contrast between cognitive and social development, as well as learning and play actions, this dichotomization neglects the fact that a similar dichotomy may be found within learning activities themselves.

\footnotetext{
${ }^{2}$ In fact, there are very few studies that identify the learning potential of child-peer activities - activities that may be structured by a teacher but take place in child-peer relationships without the teacher present (Trudge 1992; National Research Council 2001), facilitating motivation for cognitive growth (Guay, Boivin, and Hodges 1999) and development of social values (Corsaro 2005).
} 
And, within these activities observational studies often report that while the practitioner interacts with one small group of children, many other groupings of children will undertake structured cognitive/learning activities - but without the practitioner present (previously described as ‘semi-structured' learning in Fabes et al. 2007; and 'pedagogic worlds' of practitioner and peer in Kutnick et al. 2008). In these circumstances, practitioners rarely have strategies to work with multiple learning groups of children in the pre-school (Gmitrova, and Gmitrov 2003; Singer 1996), and even when practitioners have strategies to promote more inclusive relationships among pre-school children, these strategies are often focused on individual children and unlikely to focus on reciprocated relationships amongst all children within the classroom (Brown, Ragland, and Fox 1988; Buysse et al. 2003). These studies indicate that the social and relational capital generated during practitioner-structured learning time (especially when the practitioner is not present) may be undervalued and require further exploration (Clark et al. 2003; Farrell, Tayler, and Tennent 2004).

\section{Pre-school Social Pedagogies}

In making the above assertion, we draw attention to three social pedagogic considerations that warrant further explanation: 1) where children are most likely to spend their cognitive/learning time; 2) with whom children spend their cognitive/learning time; and 3) how children's active engagement with cognitive (and social) learning activities may be theorized. The first consideration notes quantitatively that pre-school children are most likely to spend their cognitive/learning time in small groups in the presence of their peers and may or may not include a practitioner within these groups (Fabes et al. 2007; Kutnick et al. 2008; Tizard, and Hughes 1984). The second consideration delves into the small group context for cognitive/learning activity and suggests (from Goble et al. 2012) that small groups or 'social contexts' are likely to be: single-sex, range in size and structure (described as 'alone', 'small group' and 'small group with practitioner') with only a small proportion of mixed-sex groups, 
and likely to engage in gender-identified activities (while groups with practitioner are likely to engage in gender-neutral activities). The understanding that children’s engagement in cognitive/learning activities will take place in particular social contexts (pedagogic worlds) opens a final consideration of how learning within these contexts may be theorized: In the relationship between social context and learning, Fabes and colleagues (especially see Martin et al. 2011; Martin 2000) focus particularly on the development of a gender identity via Gender Schema Theory (GST) in which children develop gender-based 'schemes that then influence preference for gender-types activities’ (Goble et al. 2012,p. 438) and acknowledge that gendered activity preferences are related to the composition of each small group (Goble et al. 2012). An alternate theory focuses on the actual activities in which the children engage as described in socio-cultural theory (Edwards 2003)/cultural-historical theory (Van Oers 2010). ‘Activity theory’ (originally proposed by Vygotsky 1978; adapted by Engestrom, Miettinen, and Punamaki 1999; and Daniels 2001) acknowledges that the relationship between learning stimuli and actual learning is mediated by cultural tools and may be applied in a two-fold manner: acknowledging that mediated cultural tools should include the social contexts (groups) and social contexts are likely to be dominated by culturally gendered activities.

Whilst acknowledging the interactive and inclusive pedagogy that has characterized effective pre-school provision in the UK (Sylva et al. 2010) and focusing on structured and semi-structured cognitive/learning activities, this study seeks to further describe the social contexts in which learning activities take place and, initially, assess these activities for type/composition of social context for learning. On the basis of this assessment, the study explores the range and typification of learning activities in which children engage especially with regard to social inclusion/exclusion and further questions whether differences 
in the level of cognitive challenge is associated with specific activity engagement of children within their social contexts.

\section{METHOD:}

\section{Settings and children:}

This study uses a tool to provide an in-depth account of cognitive/learning activities, actors, groups and interactions found in southeast England pre-schools. The choice of preschools was largely opportunistic; a convenience sample based upon a range of preschools that were associated with practitioner education programmes at a local university. To help with the consistency between the various pre-school settings, the study focused only on children aged between four and five years - an age when all children in England have access to pre-school experience. The use of 'setting' has been established in sample choice for pre-school research (Sylva 2010). Settings included maintained and privatelyowned pre-schools and nursery classes attached to primary schools. Staff in the preschools were qualified to a minimum of NVQ level 2 with graduates and qualified teachers. Before the study began, discussions and agreement concerning the nature of the research were undertaken with all members of staff in each setting. In addition, parents of children in each setting were informed of the content and methods of the study, and participation was agreed only with full parental consent. Further ethical criteria of anonymization, confidentiality and safe storage of data were adhered to (see ethics below).

Thirty-four pre-school settings were visited. Each setting was visited between 2 and 3 times (average number of observations sessions per setting was 2.1). Research visits allowed observations to be made once children and practitioners had established patterns of action and interaction. Multiple observations per classroom ensured that a range of cognitive/learning times were observed, and allowed for a representative sample of activities to be observed. It should be noted, though, that structured and semi-structured activities set-up for the 
children's engagement varied from visit to visit, so no assessment of reliability of activity engagement could be calculated (this methodological approach was also used in Goble at al. 2012; Harrist, and Bradley 2003; and others). Average number of children per class was 20.7; ranging from 9 to 30. All settings were mixed-sex and drew children from their local communities; there were very few children with SEN being mainstreamed in these settings. All practitioners were female and the research 'visitor' were, in the main, female.

\section{Ethics:}

There were two distinct facets to the ethical considerations made within this project; respect for practitioner and respect for child (Bassey 1999). Consent was sought from practitioners, parents/carers and children, in age appropriate ways, in the line with BERA guidance (2011). Further it was agreed between practitioners and researchers, given the tensions which can result between being a responsible adult and maintaining the naturalistic observation (Keddie 2000), that the researcher would only intervene in the children's interactions when they felt that a child could be physically or emotionally harmed by the behaviour observed.

\section{Instrument:}

Mapping was the main instrument used to describe pedagogic activity, interaction and the social context of cognitively-based learning actions in each setting. Mapping (Kutnick et. al. 2002) moves beyond a phenomenographic account wherein the context and activity of each child within the setting is recorded, and allows for depth of description as well as comparisons of learning experience across all children in the setting. The method combines both survey and observation in its approach; overcoming methodological critiques of studies such as: case-based qualitative versus means-based quantitative methods (Boaler 1997); allowing researchers to identify both number and types of setting-based actions (suggested by Hammersley 1990); and generating data that avoids simplistic binary oppositions between variables (Millard 1997; Denscombe 1998). Mapping provides an authentic picture of those 
involved in learning activities and types of activities present - allowing researchers to overcome literature-based assumptions that learning time was solely characterized by practitioner-led pedagogy. A previous study that used classroom mapping (Kutnick et. al. 2002) suggests that most children would be observed in some form of grouping (with other children) and a practitioner may or may not be present with each grouping (dependent on group size, task, etc.). Each completed map represents a unique recording of the specific actors, their social context and actions at the specific time of observation; it does not record continuity of action. While each map is unique (it does not allow for calculation of reliability over time as any other map will represent potentially different actors and actions), a number of individual maps can be combined to ascertain characteristic actions of a setting or comparisons between settings. Further, mapping differs from individual child-based observations (characterized in research by Fabes and colleagues, ex. Goble et al. 2012) in that all children as well as practitioners are included in each map - such that the full range of cognitive/learning activities and all social contexts for learning are identified at any point of time. Mapping provides a description of context within which learning takes place, and a descriptive account of Stage 1 Activity Theory (from Daniels 2001) in that the learning activity can be seen to be 'mediated' by the social and cultural context of people and groups within whom the child interacts while learning is taking place.

Mapping was undertaken by trained researchers who collaborated with practitioners to describe pedagogic actions/interactions and activities in each setting. Initially, simultaneous observations of the same settings were made by researchers for inter-rater reliability. Kappa reliability 0.94 was achieved; this high level of reliability is explained by the simplicity of data recorded and thorough discussion of the methods of data recording the ensued between researchers. After training, researchers selected a period of learning activity-time in each setting (as opposed to story/circle time or free play) and 
drew a plan/map of the physical setting that showed all physical furnishings (tables, carpeted areas, etc.) and resource areas. To ensure that a representative number and type of activities and social contexts were observed, an average of 4 maps was made per setting during each half-day visit. When the practitioner engaged all children in learning activity the researcher then noted on the map the location of individual male and female children, child work groupings, and location of adults (working with or without children). In total, 141 mappings were collected for analysis, identifying 842 groups which included 2957 recordings of children. Once a map was completed in each setting, practitioners with researchers completed a short questionnaire which provided information about each grouping identified. Information included:

1. Group size and composition: total number of children in any group (including solitary children); number of boys/girls in each group (identifying mixed- or single-sex groups); social relationship of the group (friends-only, friends/acquaintances, acquaintances-only).

2. Who composed the groups: practitioner-only selection of group members; practitioner-with-children select group members; children-only selection of group members.

3. Adult presence within the groups and type of adult activity when an adult was present: adult not present; adult observing children; adult introducing an activity; adult directing an activity; adult acting with children; and adult responding to a child.

4. Actual practitioner structured activity (undertaken by children): this activity was initially described by the researcher and then rated for type of activity, genderization of activity and cognitive challenge of activity: 
a. Typification of activity as tasks predictive of children's cognitive and social progress in pre-school (Hadeed, and Sylva 1995) included: gross motor, large construction (wooden bricks/blocks), small construction (lego, sticklebricks), art, manipulation of objects (pipe cleaners and similar objects) , structured material (sorting), pretend, scale version toys, music, informal game, spontaneous actions with rules, 3Rs (early reading and numeracy), examination of an object, problem solving, adult directed art manipulation, organized games with rules, adult-directed group activity.

b. Genderization of activity was adopted from Martin and Fabes (2001): actual activities were recoded into 29 activity categories and three additional (gender neutral) activities were included (fine motor, practitioner-led large-group story/talk, and talk with practitioner as an individual). Each of the original 29 categories was rated for its gendered nature - feminine, masculine and neutral.

c. Activity was consolidated into a reflective rating of levels of cognitive challenge (Camaioni, Bascetta, and Aureli 1988). A high level activity was defined by the presence of the following three criteria: (a) the intention to carry out a specific activity; (b) the utilization of means appropriate to accomplish the activity and (c) the pursuit of the activity. High level activities included: literacy and numeracy, symbolic play; and these activities were sub-divided into those undertaken due to practitioner direction or spontaneously. A middle level activity included only two of the three criteria, and included: spontaneous constructive activity, drawing. An intermediate score was considered and called 'Mid-high' in order to differentiate those directed activities carried on for a particular purpose such as completing a painting or acting out a scripted activity. Low and mid-low level activity showed only one of the above criteria 
and included gross and fine motor skills. Organized group activity such as listening to a story, group singing was coded as mid-low.

Analyses were undertaken at group level, allowing for an understanding of the characteristic composition of grouping with practitioner and child, child with peers and solitary children groupings within the settings. Maps also allowed for comparisons between grouping types and the learning activities within which practitioners and children participated. Each of the typifications (of activity and cognitive challenge) was rated separately by two researchers, allowing for any rater disagreements to be discussed, reconsidered and agreed before analyses could begin.

\section{RESULTS:}

\section{General group sizes and social contexts for cognitive/learning activity:}

An initial investigation into the mapping data sought to descriptively identify the various social contexts/groupings observed within the 141 maps. The 842 groupings were initially characterized by size, total number of boys and girls observed, general composition of grouping; this takes the data down to the level of the individual child and then allows for the building-up of actual contexts within which the child's learning activity takes place. Table 1 provides a general description of social contexts of the pre-school children during practitioner-assigned cognitive/learning activities (this did not include free play as children were not under practitioner direction in this activity). There was a nearly equal distribution of boys to girls throughout the study. Further, as acknowledged in a number of pre-school studies, a substantive proportion of children's time (approximately $30 \%$ of learning time) was spent alone - while there were many other children found around the classroom (see Goble et al. 2012; Ruble, Martin, and Berenbaum 2006). The majority of children’s activities (approximately 70\%) were undertaken in some form of social group, and this group was most 
likely to be a small group (composed of two to five children; approximately 60\% of activities observed). And, whether undertaking activities alone or in a group social context, practitioners were unlikely to be present (ex. no practitioner present in Alone approximately $75 \%$ of observations, and no practitioner present in groups approximately $60 \%$ of observations). Finally, within the alone and group categories, activities were likely to be undertaken in a gendered social context: 1) obviously, in the Alone context, boys and girls were observed separately, and with boys being observed alone more frequently than girls; 2) when undertaking activities in a group context, children were more likely to work in a singlesex rather than a mixed-sex group, and male-only single-sex groups were observed slightly more frequently than female-only groups. At this general level, the social context of children’s learning experience was likely to be undertaken as a group - and when one considers the gender-based inclusive context for learning (whether alone or with a group) learning activities were most likely approached within a single-sex social context. Moreover, most of the children's learning activities were undertaken without a practitioner or informed adult present.

TABLE 1 ABOUT HERE

\section{Practitioner- and child-oriented groups:}

One initial way of handling the data is to explore whether/how different social contexts were related to the activities in which children participated. Similar to previous pre-school literature that describes children's activities and associated interactions with practitioners and with their peers, our early analyses seek to identify characteristics of practitioner-oriented and child-oriented pedagogic worlds. An analysis of frequencies was run on the overall group sample $(\mathrm{N}=842)$ in order to compare the distribution of Orientation to learning activity; orientation was defined as who directed the group to undertake the observed activity - which 
could be practitioner-oriented or child-oriented. As previously stated, these analyses were undertaken at the group level rather than the individual child level as groups (ranging in size from the solitary child to whole class) characterized the social context of the learning activity. There were significantly more child-oriented groups than practitioner-oriented groups in the settings; more than triple the number of child-oriented were observed compared to practitioner-oriented groups (642 versus 200; $\left(\chi^{2}[1, \mathrm{~N}=842]=232.79, \mathrm{p}<0.001\right)$ see Table 2$)$. In an average map, there were between one and two practitioner-oriented and almost four child-oriented groups.

\section{Composition of groups: a general overview}

Given that there were many more child-oriented than practitioner-oriented groups, it is only logical to expect that child-oriented groups would be smaller than practitioner-oriented groups (Table 2); child-oriented groups' average size was approximately 2 with a range of 1 to 11 , and practitioner-oriented average size was approximately 7 with a range of 1 to 30 . An ANOVA tested for differences between Orientation and Group size was statistically significant and confirmed the smaller size of child-oriented groups $(\mathrm{F}[1,840]=193.37$, $\mathrm{p}<0.0001$, eta $\mathrm{sq}=0.187)$. The table further shows that while Small group was the most frequent size of either practitioner- or child-orientation followed by Solitary, there were proportionally more Solitary and Small groups observed in the child-oriented groups and

more Large group and Whole class children observed in practitioner-oriented groups $\left(\chi^{2}[4\right.$, $\mathrm{N}=842]=161.51, \mathrm{p}<0.001)$

\section{TABLE 2 ABOUT HERE}

Analysis of group composition during learning activities was undertaken at two separate levels - a general overview and specifically within practitioner- and child-orientations. These two levels contrast potential differences between the literature-based expectation of 
interactive pedagogy, inclusion and social pedagogic contexts. The analyses identify composition, sex-mix, friendship-mix and age composition of the groupings and may be seen as interactive roots of social inclusion within setting-based learning. Who composed the groups: Decisions about group composition could be made by practitioner, children or a combination of practitioner-with-children. An analysis of frequencies (Table 2) showed that children were most likely to compose these groups, with lower proportions of practitioner composition and combined practitioner/child composition $\left(X^{2}[3, \mathrm{~N}=842]=1137.91, \mathrm{p}<0.001\right)$.

Sex composition: There was a tendency for all groups to be single-sex $\left(X^{2}[1, \mathrm{~N}=842]=\right.$ 285.15, $\mathrm{p}<0.001)$.

Friendship composition: Where friendship could be ascribed to members of a group (approximately 70\% of the groups observed when solitary children were excluded), groups were rated as Friends-only, Friends/acquaintances, Acquaintances and Individual children. Table 2 identifies that groupings were mainly characterized by Friend/acquaintances or Friends only $\left(X^{2}[2, \mathrm{~N}=427]=131.30, \mathrm{p}<0.001\right)$.

Adult presence: Observations also recorded whether practitioners were present with the various groups and, if present, what role the practitioner played. Practitioners were only present in $35.9 \%$ of the groups. When present, practitioners were most likely to Direct and scaffold or Introduce activities $\left(X^{2}[4, \mathrm{~N}=302]=145.48, \mathrm{p}<0.001\right)$.

\section{Practitioner-oriented groups only:}

With regard to practitioner-oriented groups, descriptive analyses showed groups were composed, on average, of 7 children. Excluding solitary children, groups were most likely to be composed by practitioners, with very few groups composed by children themselves or in collaboration with their practitioner. These groups were mainly Mixed-sex and, relationally, were a mix of Friend/acquaintance or Acquaintance-only. (Friend-only and children working 
Individually categories each accounted for $36.8 \%$ of observations.) Practitioners were present in $81.5 \%$ of these mappings and their role was predominantly Directive and scaffolding with a limited amount of Introduction of activities. There was a very low level of Response to child initiated actions.

\section{Child-oriented groups only:}

With regard to child-oriented groups, descriptive analyses showed very different compositional qualities from the practitioner-oriented groups. Group size averaged between 2 and 3 children. Children, predominantly, composed these groups among themselves. Groups were mainly Single-sex. Social relationships were mainly a mix of Friend/acquaintance or Solitary children; a combined friendship/solitary children found that nearly $57 \%$ of children undertook activities with those most like themselves. There were very few instances of practitioner presence (only $21.7 \%$ of observations). When a practitioner was present, she/he was likely to be Introducing an activity or Responding to/Directing a child.

\section{Summary of practitioner- and child-oriented group analysis:}

There were a number of clear compositional differences between practitioner- and childoriented groups. While children played a large role in the choice of group composition, this phenomenon only really characterized child-oriented groups. Practitioners were responsible for the composition of $69.7 \%$ of the practitioner-oriented groups. There was a statistically significant difference between the practitioner-/child-orientations with regard to composition $\left(X^{2}[2, \mathrm{~N}=839]=326.322, \mathrm{p}<0.001\right)$ with the practitioner-oriented groups showing a high level of practitioner composition and practitioner-with-child composition (Standard Adjusted Residual [sar] 17.8) and child-oriented groups were child-only composed (sar 17.5). Practitioner-oriented groups showed higher levels of heterogeneity of social relationships and sex-mix, while child-oriented groups were more homogeneous. Social relationships within groups were, generally, a mix of friends and acquaintances (analysis excluded solitary 
children): 1$)$ there was a statistically significant difference between Orientation $\left(X^{2}[2, \mathrm{~N}=\right.$ $427]=47.005, \mathrm{p}<0.001$ ) with practitioner-oriented groups most likely to be composed of acquaintances (sar 6.7) and child-oriented groups likely to be composed of friends only (sar 3.2); and 2) there was a statistically significant difference in sex composition between Orientations $\left(X^{2}[2, \mathrm{~N}=585]=26.713, \mathrm{p}<0.001\right)$ with practitioner-oriented groups likely to include mixed-sex (sar 5.2) and child-oriented groups mainly Male-only or Female-only (combined sar 5.7). From these analyses, there is a strong indication that children undertook their learning activities in separate pedagogic worlds: 1) large, heterogeneous practitioneroriented groups appeared to allow greater potential for social inclusion when undertaking activities as these groups combined boys and girls, friends and acquaintances, etc.; or 2) small, homogeneous child-oriented groups were more exclusive social and stereotypical by sex and friendship.

\section{Activity analysis:}

Actual recorded activities were coded according into Task categories (Hadeed, and Sylva 1995), levels of Cognitive challenge (Camaioni et al. 1988) and Gendered activities (from Martin, and Fabes 2001). A descriptive analysis (Table 3) across the whole sample found the 19 task categories were dominated by the traditional curriculum (3Rs; mainly undertaking number and reading practice), Artwork, Practitioner-directed artwork, Other practitionerdirected activities (story-reading), pretend activities, manipulation of toys and other puzzles and materials. An analysis of Task category by Orientation showed a statistically significant difference in the distribution of these activities between practitioner- and child-oriented groups $\left(\chi^{2}[17 \mathrm{~N}=397]=159.933, \mathrm{p}<0.0001\right)$. Differences are explained as: practitioneroriented groups showed higher proportions of Music activity (sar 2.9), 3Rs (sar 5.5) and Adult-led activities (sar 8.4); and child-oriented groups showed higher proportions of Small construction (sar 3.5), Manipulation (sar 3.2), Structured material (sar 2.6), Pretend play (sar 
3.8) and Scale version toys (sar 3.3). Thus, practitioner-oriented groups were most likely to undertake curriculum-based activities while child-oriented groups undertook other structured activities.

With regard to Cognitive challenge over the whole sample, more than $60 \%$ of activities observed were found at the mid-high level (Table 3); this finding was not surprising as this level included both practitioner-directed educational activities and children's dramatic play. There were few instances of high cognitive challenge rated. A significant difference in the distribution of Cognitive challenge by Orientation was found $\left(\chi^{2}[4 \mathrm{~N}=397]=19.527\right.$, $\mathrm{p}<0.006)$ : 1) child-oriented groups showed a higher proportion of middle, mid-low and low cognitive challenge (sar 1.8, 2.8 and 1.6 respectively); and 2) practitioner-oriented groups showed a higher proportion of mid-high (sar 4.2) activities. This result indicates that reasonably high levels of cognitive challenge were found in both practitioner- and childoriented groups, but the activities that contributed to the challenge were different for these groups; practitioner-oriented groups drew upon structured, curriculum-oriented learning activities and child-oriented groups drew upon pretend play and simulated activities.

\section{TABLE 3 ABOUT HERE}

While differences are clear in the activity orientation between practitioner- and child-oriented learning groups, initial analysis (see Table 2) also identified that grouping for learning was undertaken in a number of social contexts that were likely to be gendered. Here we draw upon social context, gender and activity definitions developed by Fabes and colleagues (especially see Martin, and Fabes 2001) in a further analysis of activity observations and note that $93.7 \%$ of the naturalistically recorded activities could be coded into the gendered categories; the other $6.3 \%$ of activities were likely to be characterized by children who were not involved in any activity. The Fabes categorization of activities was dominated by 
Artwork/drawing (15.7\%), Construction (9.6\%), Writing (8.1\%) and Toy vehicles (8.1\%); as similarly described in Table 3 task categories. The largest proportion of activities were labelled Feminine (42.0\%); 29.1\% of activities were labelled Masculine and 28.9\% of activities labelled as Neutral. From an individual child's view, most activities were defined as gender Neutral (41.6\%); this large proportion deviates somewhat from Fabes (see Goble et al. 2012) findings in that additional categories of practitioner with whole class (for Storytime/circletime) and Adult talking with child were added to the Fabes categories; these additional categories may not be observed with great frequency but were undertaken with large (often whole class) groups. Aside from the Neutral activities, 38.5\% of weighted activities were labelled as Feminine and 19.9\% labelled as Masculine. Table 4 displays a bias towards feminine activities across both Orientations although there was a significant difference between practitioner- and child-orientation $\left(\chi^{2}[2, \mathrm{~N}=2856]=483.927, \mathrm{p}<0.000\right)$. Some of the bias is explained by the categorization of Art, Writing and Books/reading as Feminine in this categorization and that pre-school practitioners were most likely to be female (who may place greater emphasis on Feminine learning activities, from Goble et al. 2012); but differences also indicate that practitioner- and child-orientations present somewhat different profiles, where there was: a relative non-existence of Masculine activities in the practitioner-orientation; Neutral activities being the largest proportion of practitioner-oriented activities; and Masculine activities accounting for approximately one-third of child-oriented activities. These differences add a further dimension to the established findings from Fabes and colleagues in that the practitioner-orientation is substantially different from the childorientation.

TABLE 4 ABOUT HERE 
Within the child-orientation, analysis reverts to a group (rather than individual) basis and provides information concerning the solitary or grouped activity context (with the grouped context differentiated into Mixed-sex, Male-only or Female-only groups). Table 5 displays: differences between activities that males and females have engaged $\left(\chi^{2}[2, N=188]=14.133\right.$, $\mathrm{p}<0.001$ ), with boys most likely to engage in Masculine activities and girls most likely to engage in Feminine activities; and differences in child-oriented groups $\left(\chi^{2}[4, \mathrm{~N}=406]=\right.$ 40.738, $\mathrm{p}<0.001$ ), with a roughly equal distribution between gendered and Neutral activities among Mixed-sex groups, boys most likely to engage in Masculine activities and girls most likely to engage in Feminine activities.

\section{TABLE 5 ABOUT HERE}

Observations also found a high proportion of Single-sex groups in the mapping (70.1\%); 53.9\% of these Single-sex groups were Male-only and 46.1\% Female-only. Given the assertions of gender-typed cultural behaviours in the pre-school play literature (ex. Fabes et al. 2007; Maccoby 1998), a further exploration of typical activities by sex composition of groups was undertaken. There were no significant differences in average Group size or other Composition aspects aside from the sex make-up of these groups. Approximately $40 \%$ of Single-sex groups were composed of one child only, and these are excluded from the following analyses. Most of the remaining Single-sex groups were child-oriented groups (79.8\% child-oriented; 20.2\% practitioner-oriented) and there was no statistically significant difference between Male- and Female-only groups in this distribution. There was no significant difference in the role of practitioner with regard to these Single-sex groups (practitioners were only present in $23 \%$ of these observations).

Analyses explored practitioner- and child-oriented single-sex groups separately for activity engagement. There were virtually no differences in distributions for Task 
categories in practitioner-oriented groups (activities were dominated by practitioner-led 3Rs and Storytime, hence Cognitive challenge was dominated by the mid-high category). Within child-oriented activities, there was a very different display of activities between Male- and Female-only groups. There were statistically significant differences for the Task categories $\left(\chi^{2}[17 \mathrm{~N}=452]=52.971, \mathrm{p}<0.001\right)$. Differences in these categories are explained as: boys showed high proportions of Large construction (sar 2.5), Small construction (sar 3.0), Scale version toys (sar 2.9) and Adult-led group work (sar 2.0); and, girls showed high proportions of Art (sar 3.1), Pretend play (sar 2.4), 3Rs (sar 1.5) and Adult directed art (sar 2.2). These task differences were mirrored in levels of Cognitive challenge: boys showed a high proportion of mid-low (sar 2.8) and girls showed a high proportion of mid-high (sar 1.9). In line with research by Fabes and colleagues, further analyses explored for gender-based differences between Solitary and Mixed- and Singlesex groups. Previous analyses (above) have already identified that in both Solitary and Single-sex groupings, children were most likely to pursue activities in line with their gender identity, thus these analyses focus on the relationship between activities undertaken in the various social contexts and the levels of cognitive challenge involved.

\section{Activities and cognitive challenge:}

Levels of cognitive challenge as defined by Camaioni et al. (1988) presented a bimodal distribution with peaks at middle and mid-high categories. There was a significant difference in Cognitive challenge between practitioner- and child-oriented groups $\left(\chi^{2}\right.$ [5 $\mathrm{N}=778]=130.970, \mathrm{p}<0.001$ ), with: practitioner-oriented groups showing higher proportions of mid-low (sar 4.7), directed high (sar 5.8) and high (sar 5.1) challenge; and child-oriented groups showing higher proportions of low (sar 3.6), middle (sar 7.9) and high-middle (sar 3.2) challenge. Variation within the child-oriented activities is of particular interest, following the earlier differences (Table 5) identified in the gendered 
orientation in activities. A gross cross tabulation of gendered activities by Cognitive challenge was significant $\left(\chi^{2}[10 \mathrm{~N}=590]=270.634, \mathrm{p}<0.001\right)$, showing: Feminine activities had high proportions of high-middle (sar 12.2) and high (sar 5.3) challenge; Masculine activities had high proportions of mid-low (sar 2.5) and middle (sar 7.7) challenge; and neutral activities had high proportions of low (sar 5.5) and middle (sar 2.8) challenge. As Goble et al (2012) has pointed out, activity differences often relate to social context, and questions whether children undertaking solitary or grouped activities may represent different profiles of cognitive challenge. As displayed in Table 6, there is a rough parity in the levels of Cognitive challenge when children undertake activities as solitary individuals or as a member of a small group - both contexts show that males are more likely to undertake activities of lower cognitive challenge than females (solitary: $\chi^{2}$ $[5 \mathrm{~N}=185]=11.542, \mathrm{p}<0.042$; and small group: $\left.\chi^{2}[10 \mathrm{~N}=485]=28.541, \mathrm{p}<0.001\right)$. Solitary boys showed higher proportions of mid-low (sar 2.0) and middle (sar 2.1) while Small group boys showed higher proportions of middle (sar 3.7) cognitive challenge. Solitary girls showed higher proportions of directed high (sar 2.0) while Small group girls showed higher proportions of high-middle (sar 3.8) and directed high (sar 1.2) cognitive challenge. There is a strong indication that the gendered activities engaged in by childoriented groups provided less intellectual/cognitive challenge for boys than for girls. And, it is of note that there is no significant difference in levels of cognitive challenge in the comparison of female-only and mixed-sex groups.

\section{TABLE 6 ABOUT HERE}

\section{Inclusive or exclusive groups:}

From the analyses above, various social contexts and compositions of groups were evident in children’s learning activities. Since inclusive groups represent both a goal and tool of 
pedagogic activity within many pre-school curricula, we add a further analysis to further investigate whether cognitive/learning activities were undertaken in a socially inclusive manner. To undertake this analysis, Orientation was assessed by inclusivity/exclusivity of groups as they undertook their learning activities. This analysis required the computation of a new variable named Inclusion (for groups that were Mixed-sex, Friend/acquaintance-mix or Acquaintances-only). The Inclusion variable initially identifies that children's learning activities were mainly undertaken in an exclusive social context (either as a solitary learner, or in single-sex or friendship-only groups); $27.6 \%$ (232 of 842 ) of the groups observed were identified as inclusive although when solitary children are excluded from the calculation the inclusive percentage rises to $39.7 \%$ (232 of 585 groups). A cross tabulation of Inclusion by Orientation found that inclusive groups were most likely to be practitioner-oriented (all groups: $\chi^{2}[1 \mathrm{~N}=842]=47.171, \mathrm{p}<0.001$ and groups excluding solitary children $\chi^{2}[1 \mathrm{~N}=585]$ $=30.430, \mathrm{p}<0.001)$. While inclusive groups were most likely to be practitioner-oriented, other characteristics show inclusive groups to be: a) larger (inclusive 6.69, exclusive 3.25, $\mathrm{F}[1,583]=77.250, \mathrm{p}<0.001$, eta $=0.117)$; b) more likely to be composed by a practitioner (inclusive 42.7\%, exclusive $15.3 \%\left(\chi^{2}[1 \mathrm{~N}=585]=54.648, \mathrm{p}<0.001\right)$; c) more likely to have a practitioner present (inclusive 53.0\%, exclusive 32.3\%, $\left(\chi^{2}[5 \mathrm{~N}=585]=26.848, \mathrm{p}<0.001\right)$;

d) pursuing Fabes' definition of neutral activities (inclusive: neutral $>$ feminine $>$ masculine, exclusive: feminine>masculine $>$ neutral, $\left(\chi^{2}[2 \mathrm{~N}=585]=19.607, \mathrm{p}<0.001\right)$; and e $)$ undertaking activities of higher cognitive challenge: inclusive characterized by Directed High, exclusive characterized by Medium, $\left(\chi^{2}[5 \mathrm{~N}=585]=13.950, \mathrm{p}<0.016\right)$.

\section{Summary of activity and social context of group findings:}

Learning activities, as analysed through this section, were undertaken in various social contexts that, perhaps, lead to a confirmation that pre-school children's learning takes place in diverse 'pedagogic worlds'. This diversity is explained in the following manner: 
At a general level, the dominant activities are characterized by developing a readiness to enter primary school - activities include 3Rs, artwork and practitioner-directed actions. But, when social context was considered, there were clear differences found between practitioner- and child-oriented activities and further differences within the child-oriented activities. These social context differences are explained by:

- Activity: practitioner-oriented activities were strongly related to school readiness while child-oriented were more likely to be cognitive/play related (with toys and pretend/drama). Within child-oriented groups, boys were more likely to undertake scripted, toy-related activities while girls undertook unscripted pretend/drama.

- Cognitive challenge: practitioner-oriented activities were likely to be at midhigh/directed high levels of challenge while child-oriented were more likely to be at middle or lower levels of challenge. Within the child-oriented groups, boy-only groups were characterized by low and middle level challenge while girl-only and mixed-sex groups were characterized by mid-high/directed high levels of challenge.

- Gendered activities: practitioner-oriented activities were most likely to be gender neutral, followed by feminine while child-oriented activities were strongly gendered - with boy-only groups likely to pursue masculine activities, female-only groups likely to pursue feminine activities and mixed-sex groups pursued a mix of gendered and neutral activities.

- Inclusive/exclusive: practitioner-oriented activities were most likely to be undertaken in inclusive groups (mixes of sex and friendship/acquaintance) while child-oriented groups (especially the single-sex groups) undertook activities in a manner dominated by the sex of the child and friendship.

\section{DISCUSSION:}


Acknowledging the potential benefits of high quality pre-school provisions which operate within an inclusive/interactive pedagogy, this study set out to explore the range of social contexts children experience at pre-school when undertaking cognitive/learning activities. Our methods, though, moved away from a complex quantification of cognitive, social and environmental measures to focus on actual learning activities that were undertaken by children within the social pedagogic contexts.

The mapping method provided insight with regard to the nature, quality and social context of pre-school learning activity that has not characterized previous large-scale studies. Mapping allowed insight into activity engagement by all children within the setting rather than focusing solely on practitioner-pupil (pedagogic) interactions or cognitive/social outcomes. Results of the learning activity mapping supported previous research (for example, Siraj-Blatchford, and Sylva 2004), but only in part. Observations identified that learning activity was undertaken by children in some form of group but groups were dominated by two distinct orientations - practitioner-oriented and child-oriented. Practitioner-oriented groups demonstrated similarities to the interactive/inclusive pedagogy. These groups were (relatively) large and undertook mid-high/high cognitive challenge in activity areas that may be considered as contributory to school readiness (early mathematics, literacy, etc.). The focused practitioner-with-pupil interactions showed similarities to 'sustained shared thinking' described by Siraj-Blatchford (2010). At a social pedagogic level, these practitioner-oriented groups included boys and girls, friends and acquaintances. These groups were composed of practitioner and child preferences and the activities engaged in were either gender neutral or feminine (based upon pre-school gender definitions from Martin, and Fabes 2001). In another social pedagogic context, activities in child-oriented groups were interactive; although there were a number of children who undertook these activities in a solitary manner. Learning activities undertaken by the majority of child-oriented groups were characterized by a context 
of homogeneity of sex and friendship. These activities had distinct gender orientations - with female groups more likely to undertake school preparatory activities supported by role play and male groups more likely to undertake scripted actions with toys and manipulative objects (building blocks, etc.). The gendered orientations to activity were, obviously, socially exclusive and differentiated by level of cognitive challenge (females associated with midhigh/high and males associated with low) and orientation to future primary schooling (females oriented to 3Rs and males oriented to toys). This finding of gender differentiation within child-oriented groups raises concerns similar to those associated with free play (Fabes et al. 2007) - although applied to children's learning activities when a practitioner is not present.

In an attempt to introduce a systematic explanation for inclusion and sex differences within the children's practitioner- and peer-oriented worlds, we draw upon consideration of activity theory first introduced by Vygotsky (1978; Cole 1996) and expanded by Daniels (2001) and Engestrom, Miettinen, and Punamaki (1999). All learning activities took place in an 'interactive social environment' wherein the relationship between the stimulus of each learning activity and resultant learning by the child was 'mediated' by culturally defined tools. If we define the social pedagogic context within which activities were engaged as a culturally defined tool, then 'first generation activity theory' (Daniels 2001, p.85-6) identifies that: 1) practitioner-oriented mediation is likely to associate children’s learning opportunities with interactive and inclusive cultural practices (also see Deans 2009) that are also associated with higher levels of cognitive challenge; and 2) child-oriented mediation is likely to associate learning opportunities with interactive but exclusive cultural practices. To extend, with regard to child-oriented groups, an activity theory explanation focuses on gendered socio-cultural environments that both differentiates activity choice/cognitive challenge between boys and girls as well as sets an exclusive relational profile within which children 
are likely to engage in their non-practitioner-present learning (in anticipation of entry into primary school). As children develop through their pre-school years, we expect (as does Fabes et al. 2003, 2007; Goble et al. 2012) that children will see as 'legitimate' that many of their learning activities will be separated by sex. Moreover, these socially exclusive activities are differentiated by lower levels of cognitive demand for boys than girls, consistent with findings on the socially exclusive nature of free play (Fabes et al. 2007; Lofdahl, and Hagglund 2006; Gunn at al. 2004; Odom et al. 2002; Kontos, and Wilcox-Herzog 1997). Our results point out that the child-oriented pedagogic world may set precedence for sex differentiated patterns of learning found in the primary school and after; although we should identify (with justification from the above results) that practitioners can/should play a larger role with regard to the composition/structuring of the predominantly gendered child-oriented groups - thus challenging (especially male-only groups) to be more socially inclusive and with the propensity to engage in more high challenge cognitive activities.

\section{References:}

Ball, C. 1994. Start Right: The importance of early learning. London: Royal Society for the Encouragement of Arts.

Bassey, M. 1999. Case Study Research in Educational Settings, Buckingham: Open University Press.

BERA. British Education Research Association. 2011. 'Revised ethical guidelines for educational research’. Online. Available at: http://www.bera.ac.uk; accessed 5 February 2014.

Bertram, T., and C. Pascal. 2002. Early years education; an international perspective. London: Qualifications and Curriculum Authority.

Boaler, J. 1997. Setting, Social Class and Survival of the Quickest. British Educational Research Journal. 23 (5) 575-595.

Brandsma, J. 2003. Education, equality and social exclusion. University of Twente, Netherlands

(http://ftp.cordis.lv/pub/improving/docs/ser_clusters_education_social_exclusion_synthes is.pdf; accessed 8 March 2013).

Brown, W.H., E.U. Ragland, and J.F. Fox. 1988. Effects of group socialization procedures on the social interactions of preschool children. Research in Developmental Disabilities, 9 (4): 359-376.

Buysse, V., B.D. Goldman, and M.L. Skinner. 2003. Friendship formation in inclusive early education classrooms: What is the teacher's role? Early Childhood Research Quarterly, 18 (4): 485-501. 
Camaioni, L., C. Bascetta, and T. Aureli. 1988. L'osservazione del bambino nel contesto educativo. Bologna, IT: Il Mulino.

Clark, A., R.C. Anderson, L. Kuo, A. Archididou, and K. Nguyen-Jahiel. 2003. Collaborative reasoning: expanding ways for children to talk and think in school. Educational Psychology Review, 15: 181-198.

Cole, M. 1996. Cultural psychology: a once and future discipline. Cambridge, MA: Harvard University Press.

Corsaro, W.A. 2005. The sociology of childhood. Thousand Oaks, CA: Pine Forge.

Daniels, H. 2001. Vygotsky and pedagogy. London: Routledge-Falmer.

Deans, J. 2009. Friends on the farm- Reciprocal relationship building through the arts. UNESCO Observatory, Faculty of Architecture, Building and Planning, The University of Melbourne (e-Journal), 1 (4). June.

Denscombe, M. 1998. The good research guide. Buckingham: Open University Press.

DfEE/QCA. 2000. Inclusion: Providing effective learning opportunities for all pupils in the National Curriculum for England and Wales. http://www.nc.uk.net/nc resources/html/inclusion.shtml. Accessed 22 July 2011.

Early, D.M., K.L. Maxwell, M. Burchinal, S. Alva, R.H. Bender, D. Bryant, K. Cai, R.M. Clifford, C. Ebanks, J.A. Griffin, G.T. Henry, C. Howes, J. Iriondo-Perez, H.-J. Jeon, A.J. Mashbutn, E. Peisner-Feinberg, R.C. Pianta, N. Vandergrift, and N. Zill. 2007. Teachers' education, classroom quality, and young children's academic skills: results from seven studies of preschool programs. Child Development, 78: 558-580.

Edwards, S. 2003. New Directions: charting the paths for the role of sociocultural theory in early childhood education and curriculum. Contemporary Issues in Early Childhood, 4, (3): 251-265. As cited in: Deans, J. 2009. Friends on the farm- Reciprocal relationship building through the arts. UNESCO Observatory, Faculty of Architecture, Building and Planning, The University of Melbourne (e-Journal), 1 (4). June.

Effective Provision of Pre-school (EPPE) Project. 2004. Technical Paper 11 - Report on the continuing effects of pre-school education at age 7. London: University of London, Institute of Education.

Engeström, Y., R. Miettinen, and R.J. Punamaki.1999. Perspectives on activity theory. Cambridge: Cambridge University Press.

Fabes, R.A., L.D. Hanish, and C.L. Martin. 2003. Children at play: the role of peers in understanding the effects of child care. Child Development, 74 (4): 1039-1043.

Fabes, R. A., L.D. Hanish, and C.L. Martin. 2007. Peer interactions and the gendered social ecology of preparing young children for school. Early Childhood Services, 1: 144-57.

Fanger, M.F., L.A. Frankel, and N, Hazen. 2012. Peer exclusion in preschool children's play: naturalistic observations in a playground setting. Merrill-Palmer Quarterly, 58 (2): 224254/

Farrell, A., C. Tayler, and L. Tennent. 2004. Building social capital in early childhood education and care: an Australian study. British Educational Research Journal, 30 (5): $623-632$.

Goble, P., C.L. Martin, L.D. Hanish, and R.A. Fabes. 2012. Children's gender-types activity choices across preschool social contexts. Sex Roles, 67: 435-451.

Gmitrova, V., and J. Gmitrov. 2003.The Impact of Teacher-Directed and Child-Directed Pretend Play on Cognitive Competence in Kindergarten Children, Early Childhood Education Journal, 30 (4): 241-246.

Guay, F., M. Boivin, and E.V.E. Hodges. 1999. Predicting change in academic achievement: a model of peer experiences and self-system processes. Journal of Educational Psychology, 91: 105-115. 
Gunn, A., C. Child, B. Madden, K. Purdue, N. Surtees, B. Thurlow, and P. Todd, P. 2004. Building inclusive communities in early childhood education: diverse perspectives from Aotearoa/New Zealand. Contemporary Issues in Early Childhood, 5 (3): 293-307.

Hadeed, J., and K. Sylva. 1995. Behavioural Observations as Predictors of Children's Social and Cognitive Progress in Day Care. Paper presented at the European Conference on Early Childhood Education. Paris, France, September 1995.

Hammersley, M. 1990. What's wrong with ethnography: the myth of theoretical description. Sociology, 24 (4): 597-615.

Harrist, A.W., and K.D. Bradley. 2003. "You can’t say you can’t play”: intervening in the process of social exclusion in the kindergarten classroom. Early Childhood Research Quarterly, 18: 185-205.

Keddie, A. 2000. Research with young children: some ethical considerations, Journal of Educational Enquiry, 1 (2), 72-81.

Kontos, S. 1999. Pre-school teachers' talk, roles, and activity settings during free play. Early Childhood Research Quarterly, 14 (3): 363-382.

Kontos, S., and A. Wilcox-Herzog, A. 1997. Influences on children's competences in early childhood classrooms. Early Childhood Research Quarterly, 12: 247-262.

Kutnick, P., and A. Brighi with S. Avgitidou, M.L. Genta, M. Hannikainen, M. KarlssonLohmander, and R. Ortega Ruiz. 2007. The role and practice of interpersonal relationships in European early education settings: sites for enhancing social inclusion, personal growth and learning? European Early Childhood Education Research Journal, 15 (3): 379-406.

Kutnick, P., P. Blatchford, and E. Baines. 2002. Pupil groupings in primary school classrooms: sites for learning and social pedagogy? British Educational Research Journal, 28 (2): 189-208.

Kutnick, P., M.L. Genta, A. Brighi, and A. Sasavini. 2008. Relational approaches in early education: Enhancing social inclusion and personal growth for learning Bologna, IT: Cooperativa Libraria Universitaria Editrice Bologna.

Lofdahl, A. and S. Hagglund. 2006. Power and participation: social representation among children in pre-school. Social Psychology of Education, 9 (2): 179-194.

Maccoby, E.E. 1998. The two sexes: Growing up apart, coming together. Cambridge, MA: Belknap.

Martin, C. L. 2000. Cognitive theories of gender development. In T.Eckes and H. M. Trautner (Eds.), The developmental social psychology of gender (pp. 91-121). Mahwah: Erlbaum.

Martin, C. L., and R.A. Fabes. 2001. The stability and consequences of young children's same-sex peer interactions. Developmental Psychology, 37: 431-446.

Martin, C. L., R.A. Fabes, L. Hanish, S. Leonard, L.M. Dinella. 2011. Experienced and expected similarity to same-gender peers: Moving toward a comprehensive model of gender segregation. Sex Roles, 65: 421-434.

Millard, E. 1997. Differently literate. London: Falmer Press.

Myrdal, A. 1945. A Swedish experiment in democratic family and population policy. London: Kegan Paul, Trench \& Truber.

National Institute of Child Health and Development (NICHD). 2002. Early child care and children's development prior to school entry: results from the NICHD Study of Early Child Care. American Education Research Journal, 39 (1): 133-164.

National Research Council. 2001. Eager to learn. Washington D.C.: National Academy Press.

Nutbrown, C. and Clough, P. (2004). Inclusion and exclusion in the early years. European Journal of Special Educational Needs, 19 (3), 301-15. 
Odom, S. 2000. Preschool inclusion: what we know and where we go from here. Topics in Early Childhood Special Education, 20(1): 20-27.

Odom, S. L., C. Zercher, J. Marquart, S. Li, S.R. Sandall, and P. Wolfberg, P. 2002. Social relationship of children with disabilities and their peers in inclusive preschool classrooms. In S. L. Odom (Ed.) Widening the circle: Including children with disabilities in preschool programs (pp. 61-80). New York: Teacher College Press.

Pellegrini A.D., J.C. Perlmutter. 1989. Classroom contextual effects on children's play, Developmental Psychology, 25 (2): 289-296.

Ruble, D. N., C.L. Martin, and S.A. Berenbaum. 2006. Gender development. In N. Eisenberg, W. Damon, and R. Lerner (Eds.). Handbook of child psychology, 6th ed.: Vol 3. Social, emotional, and personality development (pp. 858-932). Hoboken: Wiley.

Sammons, P., K. Elliot, K. Sylva, E. Melhuish, I. Siraj-Blatchford, and B. Taggart, B. 2004. The impact of pre-school on young children's cognitive attainments at entry to reception, British Educational Research Journal, 30 (5): 691-712,

Schweinhart, L.J., and D.P. Weikart. 1997. The high/scope preschool curriculum comparison through age 23. Early Childhood Research Quarterly, 12 (2): 117-43.

Singer, E. 1996. Prisoners of the method: Breaking open the child-centred pedagogy in day care centres, International Journal of Early Years Education, 4 (2): 28-40.

Siraj-Blatchford, I. 2010. A focus on pedagogy: Case studies of effective practice. In K. Sylva, E. Melhuish, P. Sammons, I. Siraj-Blatchford, and B. Taggert (Eds.). Early childhood matters: Evidence from the effective pre-school and primary education project (pp. 149-165). London: Routledge.

Siraj-Blatchford, I., Sylva, K., Taggart, B., Sammons, P., Melhuish, E. C. and Elliot, K. (2003) 'The effective provision of pre-school education (EPPE) project: technical paper 10 intensive case studies of practice across the foundation stage', Nottingham: DFES Publications.

Siraj-Blatchford, I., and K. Sylva. 2004. Researching pedagogy in English pre-schools, British Education Research Journal, 30 (5): 713-730.

Social inclusion and early childhood education. 2009. Australian Government: Department of Education, Employment and Workplace Relations.

Stephen, C. 2006. Early years education: perspectives from a review of the international literature. Edinburgh: Information and Analytical Services Division, Scottish Executive Education Department.

Sylva, K. 2010. Quality in early childhood settings. In K. Sylva, E. Melhuish, P. Sammons, I. Siraj-Blatchford, and B. Taggert (Eds). Early childhood matters: Evidence from the effective pre-school and primary education project (pp. 70-91). London: Routledge.

Sylva, K., E. Melhuish, P. Sammons, I. Siraj-Blatchford, and B. Taggert. 2010. Early childhood matters: Evidence from the effective pre-school and primary education project. London: Routledge.

Smith, P., and K. Connolly. 1980. The ecology of preschool behaviour. Cambridge, Cambridge University Press.

Tizard B., P. Blatchford, J. Burke, C. Farquhar, and I. Plewis. 1988. Young children at school in the inner city. Hove: Lawrence Erlbaum.

Tizard, B., and M. Hughes. 1984. Children learning at home and in school. London: Fontana.

Trudge, J. 1992. Processes and consequences of peer collaboration: A Vygotskian analysis. Child Development, 63: 1364-1379.

Van Oers, B. 2010. Emergent mathematical thinking in the context of play. Educational Studies in Mathematics, 74: 23-37.

Vygotsky, L. 1978. Mind in society: The development of higher mental processes. Cambridge: Harvard University Press. 
Woodhead, M. and D. Faulkner. 2000. Subjects, objects or participants? Dilemmas of psychological research with children. In P. Christiansen and A. James (Eds.).

Research with children: Perspectives and practices, London: Falmer Press. 
Table 1: Group sizes and social contexts for cognitive/learning activity (\% by column)

\begin{tabular}{|c|c|}
\hline Groupings & Total observations \\
\hline $\begin{array}{l}\text { Number of boys and girls } \\
\text { observed in classroom } \\
\text { settings }\end{array}$ & $\begin{array}{r}\text { Total: } 2957 \\
\text { Boys: } 1535(51.9) \\
\text { Girls: } 1422(48.1)\end{array}$ \\
\hline $\begin{array}{l}\text { Group sizes, based on } \\
\text { groups observed }\end{array}$ & $\begin{array}{r}\text { Total: } 842 \\
\text { Alone: } 257(30.5) \\
\text { Small group (2-5): } 487(57.8) \\
\text { Medium group (6-10): } 62(7.5) \\
\text { Large group (11-20): } 13(1.5) \\
\text { Whole class: } 23(2.7)\end{array}$ \\
\hline $\begin{array}{l}\text { Groupings with/ } \\
\text { Without a practitioner } \\
\text { present }\end{array}$ & $\begin{array}{r}\text { Total: } 842 \\
\text { Alone without T: } 192(74.7) \\
\text { Alone with T: } 65(25.3) \\
\text { Group without T: } 348(59.5) \\
\text { Group with T: } 237(40.5)\end{array}$ \\
\hline $\begin{array}{l}\text { Gender Composition of } \\
\text { groups }\end{array}$ & $\begin{array}{r}\text { Alone: Total: } 257 \\
\text { Male: } 142 \text { (55.3) } \\
\text { Female: } 115(44.7) \\
\text { Group: Total: } 585 \\
\text { Mixed-sex: } 252(43.1) \\
\text { Single-sex: } 333 \text { (59.6) } \\
\text { Male-only: } 176 \text { (52.9) } \\
\text { Female-only: } 157(47.1)\end{array}$ \\
\hline
\end{tabular}


Table 2: Composition of groups overall and for practitioner- and child-orientations; proportions by composition categories ${ }^{1}$

\begin{tabular}{|c|c|c|c|}
\hline $\begin{array}{l}\text { Orientation/ } \\
\text { Composition factors }\end{array}$ & Overall & $\begin{array}{l}\text { Practitioner- } \\
\text { oriented }^{2}\end{array}$ & Child-oriented \\
\hline Average Group Size & $3.51(\mathrm{SD}=4.43)$ & $6.95(\mathrm{SD}=7.72)$ & $2.44(\mathrm{SD}=1.57)$ \\
\hline $\begin{array}{l}\text { Total number of groups } \\
\text { (\% by row) }\end{array}$ & 842 & $200(23.8 \%)$ & $642(76.2 \%)$ \\
\hline $\begin{array}{l}\text { Size of groups: (\% by } \\
\text { column) }\end{array}$ & & & \\
\hline Solitary & 257 (30.5) & 39 (19.5) & $218(34.0)$ \\
\hline Small group & 487 (57.8) & $91(45.5)$ & $396(61.7)$ \\
\hline Medium group & $62(7.5)$ & 35 (17.5) & $27(4.2)$ \\
\hline Large group & $13(1.5)$ & $12(6.0)$ & $1(0.2)$ \\
\hline Whole class & $23(2.7)$ & 23 (11.5) & $0(0.0)$ \\
\hline $\begin{array}{l}\text { Who Composed (\% by } \\
\text { column }\end{array}$ & & & \\
\hline Practitioner & $194(23.0)$ & $138(69.0)$ & $56(8.7)$ \\
\hline Children & $615(73.0)$ & $50(25.0)$ & $565(88.0)$ \\
\hline Mixed & $30(3.6)$ & $10(5.0)$ & $20(3.1)$ \\
\hline Not identified* & $3(0.04)$ & $2(1.0)$ & $1(0.2)$ \\
\hline $\begin{array}{l}\text { Sex Mix (\% by } \\
\text { column) }\end{array}$ & & & \\
\hline Mixed-sex & 176 (20.9) & $56(28.0)$ & $120(18.7)$ \\
\hline Single-sex & $666(79.1)$ & $144(72.0)$ & $522(81.3)$ \\
\hline $\begin{array}{l}\text { Social Relationship (\% } \\
\text { by column) }\end{array}$ & & & \\
\hline Friend & $144(17.1)$ & $16(8.0)$ & 98 (15.3) \\
\hline Friend/Acquaintance & $250(29.7)$ & $54(27.0)$ & $196(30.5))$ \\
\hline Acquaintance & $63(7.5)$ & $37(18.5)$ & $26(4.0)$ \\
\hline Individual & 233 (27.7) & 37 (18.5) & $196(30.5))$ \\
\hline Not identified* & $152(18.1)$ & $56(28.0)$ & $126(19.6)$ \\
\hline $\begin{array}{l}\text { Role of Adult (\% by } \\
\text { column) }\end{array}$ & & & \\
\hline Not present & $540(64.1)$ & 37 (18.5) & $503(78.3)$ \\
\hline Observes & $37(4.4)$ & $13(6.5)$ & $24(3.7)$ \\
\hline Introduces & $91(10.9)$ & 33 (16.5) & $58(9.0)$ \\
\hline Direct/Scaffold & $127(15.1)$ & $100(50.0)$ & $27(4.2)$ \\
\hline Acts with & $15(1.8)$ & $13(6.5)$ & $2(0.3)$ \\
\hline Responds to child & $32(3.8)$ & $4(2.0)$ & $28(4.4)$ \\
\hline
\end{tabular}

${ }^{1}$ For the analysis, data were weighted by the number of children in each group. Since the results did not vary between weighted and non-weighted analyses, we chose to report the non-weighted results here.

${ }^{2}$ Descriptions in the practitioner-oriented column excluded solitary children.

*Where 'not identified' occurred in the observations, there frequencies were noted as missing. 
Table 3: Frequency of Task Categories (from Hadeed and Sylva 1995) with Levels of Cognitive Challenge (from Camaioni et al., 1988) within groups: overall and for practitionerand child-oriented groups (\% by column)

\begin{tabular}{|c|c|c|c|c|}
\hline $\begin{array}{l}\text { Orientation/ Task } \\
\text { Categories }\end{array}$ & $\begin{array}{l}\text { /Levels of } \\
\text { cognitive } \\
\text { Challenge }\end{array}$ & Overall & $\begin{array}{l}\text { Practitioner- } \\
\text { oriented }\end{array}$ & Child-oriented \\
\hline Gross motor & Low & $15(3.8)$ & $2(1.6)$ & $13(4.8)$ \\
\hline Large construction & Mid-low & $8(2.0)$ & $0(0.0)$ & $8(3.0)$ \\
\hline Manipulation & Mid-low & $37(9.3)$ & $3(2.4)$ & $34(8.6)$ \\
\hline Music & Mid-low & $4(1.0)$ & $4(3.2)$ & $0(0.0)$ \\
\hline Small construction & Middle & $30(7.6)$ & $1(0.8)$ & $29(10.7)$ \\
\hline Art & Middle & $46(11.6)$ & $17(13.5)$ & $29(10.7)$ \\
\hline Informal games & Middle & $2(0.5)$ & $0(0.0)$ & $2(0.7)$ \\
\hline $\begin{array}{l}\text { Non-playful } \\
\text { interaction }\end{array}$ & Middle & $4(1.0)$ & $2(1.6)$ & $2(0.7)$ \\
\hline Examination & Middle & $3(0.8)$ & $0(0.0)$ & $3(1.1)$ \\
\hline Structured material & Mid-high & $25(6.3)$ & $2(1.6)$ & $23(8.5)$ \\
\hline Pretend & Mid-high & $35(8.8)$ & $1(0.8)$ & $34(12.5)$ \\
\hline Scale version toys & Mid-high & $28(7.1)$ & $1(0.8)$ & $27(10.0)$ \\
\hline $\begin{array}{l}\text { Social spontaneous } \\
\text { rules }\end{array}$ & Mid-high & $1(0.3)$ & $0(0.0)$ & $1(0.4)$ \\
\hline $\begin{array}{l}\text { Practitioner } \\
\text { directed art }\end{array}$ & Mid-high & $32(8.1)$ & $11(8.7)$ & $21(7.7)$ \\
\hline $\begin{array}{l}\text { Adult-led directed } \\
\text { activity }\end{array}$ & Mid-high & $33(8.3)$ & $32(25.4)$ & $1(0.4)$ \\
\hline $3 \mathrm{Rs}$ & Mid-high & $90(22.7)$ & 50 (39.7) & $40(14.8)$ \\
\hline $\begin{array}{l}\text { Organized games } \\
\text { with rules }\end{array}$ & Mid-high & $2(0.5)$ & $0(0.0)$ & $2(0.7)$ \\
\hline Problem solving & High & $2(0.5)$ & $0(0.0)$ & $2(0.7)$ \\
\hline \multicolumn{2}{|c|}{$\begin{array}{l}\text { Orientation/ Average Levels of } \\
\text { Cognitive Challenge }\end{array}$} & Overall & $\begin{array}{l}\text { Practitioner- } \\
\text { oriented }\end{array}$ & Child-oriented \\
\hline \multicolumn{2}{|l|}{ Low } & $15(3.8)$ & $2(1.6)$ & $13(4.8)$ \\
\hline \multicolumn{2}{|l|}{ Mid-low } & $49(12.3)$ & $7(5.6)$ & 42 (15.5) \\
\hline \multicolumn{2}{|l|}{ Middle } & $85(21.4)$ & $20(15.9)$ & $65(24.0)$ \\
\hline \multicolumn{2}{|l|}{ Mid-high } & $246(62.0)$ & $97(77.0)$ & $149(55.0)$ \\
\hline \multicolumn{2}{|l|}{ High } & $2(0.5)$ & $0(0.0)$ & $2(0.5)$ \\
\hline \multicolumn{2}{|l|}{ Totals } & 397 & 126 & 271 \\
\hline
\end{tabular}

Table 4: Weighted comparison of gendered activity by orientation (\% by column)

\begin{tabular}{|l|r|r|r|}
\hline Orientation/Gender & Both orientations & Practitioner-oriented & Child-oriented \\
\hline Feminine & $1108(38.8)$ & $543(39.4)$ & $565(38.2)$ \\
\hline Masculine & $571(19.9)$ & $57(4.1)$ & $514(34.8)$ \\
\hline Neutral & $1177(41.2)$ & $777(56.4)$ & $400(27.0)$ \\
\hline Totals & 2856 & 1377 & 1479 \\
\hline
\end{tabular}


Table 5: Frequencies of group-based activities observed among child-oriented groupings (\% by column)

\begin{tabular}{|l|r|r|r|r|r|}
\hline & \multicolumn{3}{l|}{ Solitary activity } & \multicolumn{2}{l|}{ Grouped activity } \\
\hline $\begin{array}{l}\text { Gendered } \\
\text { activity/grouping }\end{array}$ & \multicolumn{1}{l|}{ Males } & Females & \multicolumn{1}{l|}{ Male } & \multicolumn{1}{l|}{ Female } & \multicolumn{1}{l|}{ Mixed-sex } \\
\hline Feminine & $30(30.3)$ & $50(56.2)$ & $25(18.4)$ & $65(52.0)$ & $54(37.2)$ \\
\hline Masculine & $40(40.4)$ & $18(20.2)$ & $77(56.6)$ & $29(23.2)$ & $51(35.2)$ \\
\hline Neutral & $29(29.2)$ & $21(23.6)$ & $34(25.0)$ & $31(24.8)$ & $40(27.6)$ \\
\hline Totals & 99 & 89 & 136 & 125 & 145 \\
\hline
\end{tabular}

Table 6: Frequencies of levels of cognitive challenge within social contexts of activities observed among child-oriented groupings (\% by column)

\begin{tabular}{|l|r|r|r|r|r|}
\hline & \multicolumn{2}{l|}{ Solitary activity } & \multicolumn{2}{l|}{ Grouped activity } \\
\hline $\begin{array}{l}\text { Cog } \\
\text { challenge/grouping }\end{array}$ & \multicolumn{1}{l}{ Males } & \multicolumn{1}{l}{ Females } & Female & Mixed-sex \\
\hline Low & $4(4.1)$ & $3(3.4)$ & $11(8.1)$ & $7(5.6)$ & $13(9.0)$ \\
\hline Mid-low & $7(7.1)$ & $1(1.1)$ & $6(4.4)$ & $4(3.2)$ & $5(3.4)$ \\
\hline Middle & $44(44.9)$ & $26(29.9)$ & $65(47.8)$ & $29(23.4)$ & $50(35.5)$ \\
\hline High-middle & $16(16.3)$ & $20(23.0)$ & $13(9.6)$ & $37(29.8)$ & $26(17.9)$ \\
\hline Directed High & $18(18.4)$ & $27(31.0)$ & $27(19.9)$ & $35(28.2)$ & $37(25.5)$ \\
\hline High & $9(9.2)$ & $10(11.5)$ & $14(10.3)$ & $12(9.7)$ & $14(9.7)$ \\
\hline Totals & 98 & 87 & 136 & 124 & 145 \\
\hline
\end{tabular}

